JURNAL PENJAMINAN MUTU

LEMBAGA PENJAMINAN MUTU

INSTITUT HINDU DHARMA NEGERI

DENPASAR

Volume 5 Nomor 1 Februari 2019

ISSN : 2407-912X (Cetak)

ISSN : 2548-3110 (Online)

http://ejournal.ihdn.ac.id/index.php/JPM

\title{
KOMITMEN PIMPINAN DALAM IMPLEMENTASI SISTEM PENJAMINAN MUTU AKADEMIK PERGURUAN TINGGI (Studi Kasus Pada STKIP PGRI Tulungagung)
}

\author{
Oleh \\ Tutut Suryaningsih ${ }^{1}$, Ali Imron ${ }^{2}$ \\ ${ }^{1}$ STKIP PGRI Tulungagung \\ ${ }^{2}$ Universitas Negeri Malang \\ tutut@stkippgritulungagung.ac.id
}

diterima 15 Desember 2018, direvisi 14 Pebruari 2019, diterbitkan 28 Februari 2019

\begin{abstract}
The quality assurance system at Higher Education (especially in STKIP PGRI Tulungagung) is a must that must be done systemically, planning and sustainable through the establishment, implementation, evaluation, control and improvement of National Education Standards. In its implementation, the quality assurance system at STKIP PGRI Tulungagung has not run in accordance with the demands of the rules that are planned in a planned and consistent manner so that quality assurance is carried out sporadically.

The results show that; first, quality assurance at STKIP PGRI Tulungagung has been carried out through the STKIP PGRI Tulungagung Education Quality Assurance Agency, while the quality assurance activities at STKIP PGRI Tulungagung are oriented towards strengthening and fulfilling the accreditation of study programs; second, the factors that become obstacles in quality assurance at STKIP PGRI Tulungagung are (a) the unavailability of quality manual documents; (b) the low level of leadership and academics, (c) human resources, (d) commitment, third communication technology systems, as well as strategies for improving quality assurance that must be carried out by institutions namely through meeting national quality standards.

The findings above are recommended; first, to the leadership of STKIP PGRI Tulungagung to improve insight, commitment and quality awareness as well quality culture through establishment, implementation and evaluation, control and increase in the National Standards for Higher Education in the STKIP PGRI Tulungagung environment
\end{abstract}

Keywords: Commitment, Quality Assurance System, Universities 


\section{PENDAHULUAN}

Pelaksanaan penjaminan mutu pendidikan (quality assurance) pada suatu Perguruan Tinggi bertujuan untuk memelihara dan meningkatkan mutu penyelenggaraan Tri Dharma Perguruan Tinggi yang berstandar secara berkelanjutan (continious improvement).

Penjaminan mutu pendidikan tinggi merupakan program yang penting dan wajib dilaksanakan oleh semua institusi penyelenggara pendidikan tinggi berdasarkan Undang-undang Nomor 12 tahun 2012 tentang Pendidikan Tinggi mengamanatkan bahwa Perguruan Tinggi harus melaksanakan dan implementasi sistem penjaminan mutu sebagai aspek yang menentukan untuk meningkatkan daya saing perguruan tinggi.

Mutu Perguruan Tinggi adalah pencapaian tujuan pendidikan dan kompetensi lulusan yang telah ditetapkan institusi pendidikan tinggi di dalam rencana strategisnya, atau kesesuaian dengan standar yang telah ditentukan. Penjaminan mutu merupakan keseluruhan aktivistas dalam berbagai dari sitem untuk memastikan bahwa mutu produk atau layanan yang dihasilkan selalu konsisten sesuai dengan yang direncanakan atau dijanjikan, didalam terkandung proses penetapan dan pemenuhan standar mutu pengelolaan pendidikan secra konsisten dan berkelanjutan, sehingga seluruh stakeholders memperoleh kepuasan.

Dengan demikian, penjaminan mutu diharapkan dapat dilakukan di seluruh perguruan tinggi dengan memperhatikan butir-butir mutu yang ditetapkan antara lain; kurikulum program studi, sumber daya manusia (dosen dan tenaga penunjang), mahasiswa, proses pembelajaran, sarana dan prasarana, suasana akademik, keuangan, penelitian, dan publikasi, pengabdian pada masyarakat, tata pamong, manajemen lembaga, system informasi, serta kerjasama dalam dan luar negeri.

Untuk pencapaian kualitas perguruan tinggi yang berkelanjutan (continuous quality improvement), pelaksanaan penjaminan mutu adalah sebuah keniscayaan, karena perguruan tinggi yang menjamin mutunya merupakan organisasi yang senantiasa memenuhi kebutuhan dan kepuasan pelanggananya. Pelanggan (costumer) yang puas akan meningkat menjadi pelanggan yang loyal dan hal ini berarti akan memberikan benefit bagi organisasi yang bersangkutan.

Berdasarakan wawancara awal menunjukkan bahwa : (1) system penjaminan mutu di STKIP PGRI Tulungagung belum dilaksanakan dengan baik, hal ini ditunjukkan dengan belum adanya pedoman penjaminan mutu; (2) tidak ada system monitoring dan evaluasi yang jelas, faktanya banyak dosen yang mengajar tidak memiliki RPS; (3) kurangnya komiten yang tinggicivitas akademika dan terjadi perbedaaan persepsi tentangpentingnya penerapan system penjamiamnan mutu.

Dari pemaparan latar belakang masalah di atas, yang menjadi pokok masalah adalah bagaimanakah Komitmen Pimpinan dalam Pelaksanaan Penjaminan Mutu di STKIP PGRI Tulungagung.

Penelitian ini bertujuan untuk menjawab rumusan masalah di atas yakni untuk mengetahui "Komitmen Pimpinan dalam Pelaksanaan Penjaminan Mutu di STKIP PGRI Tulungagung”.Tujuan ini dicapai dengan terlebih dahulu mengupayakan sebuah gambaran yang utuh tentang realitas pelaksanaan penjaminan mutu di STKIP PGRI Tulungagung, termasuk mengkaji secara kritis di dalamnya faktor-faktor yang mendukung dan menghambat pelaksanaan kebijakan penjaminan mutu di STKIP PGRI Tulungagung. Setelah itu, peneliti mencoba untuk menarik implikasi dari hasil kajian kritis ini pada upaya menggali Peran dan Gaya kepemimpinan yang secara konseptual dianggap sinergis dengan kebutuhan pelaksanaan penjaminan mutu di STKIP PGRI Tulungagung. Untuk kemudian diharapkan menjadi sumber inspirasi bagi pimpinan untuk meningkatkan komitmen mereka dalam mengantarkan STKIP menuju peningkatan mutu kelembagaannya secara konsisten dan berkesinambungan. 
Komitmen adalah sebagai perjanjian atau keterikatan untuk melakukan sesuatu yang terbaik dalam organisasi atau kelompok tertentu (Aranya \& Ferris.). Robbins dan Judge (2013), mendefinisikan komitmen sebagai suatu keadaan di mana seorang individu memihak organisasi dan tujuantujuan serta keinginan untuk mempertahankan keanggotaan dalam organisasi. Komitmen terhadap organisasi artinya lebih dari sekedar keanggotaan formal, karena meliputi sikap menyukai organisasi dan kesediaan untuk mengusahakan tingkat yang tinggi bagi kepentingan organisasi demi pencapaian tujuan.(Pandey, 2011)

$$
\text { Alien dan Meyer }
$$
mengemukakan bahwa komitmen organisasi (organizational commitment) terdiri dari tiga yaitu: "continuance commitment, affective commitment, dan ormatif commitment". Yang dimaksudkan dengan continuance commitment adalah pribadi seseorang untuk tetap bekerja pada suatu organisasi disebabkan karena ketidakmampuan mengupayakan jenis pekerjaan yang lain. Dan affective commitment adalah kekuatan keinginan seseorang untuk terus bekerja pada suatu organisasi disebabkan karena kesesuaian dan keinginannya, sementara normative commitment merujuk pada perasaan kewajiban seseorang untuk tetap pada suatu organisasi karena adanya tekanan atau daya tarik.

Pendapat yang senada dikemukakan Fred Luthans $(2012,147)$ yang menyatakan bahwa komitmen organisasi merupakan "...loyalty to their organization and is an ongoing process through which organizational participants express their concern for the organization and its continued success and well-being."

Budaya organisasi mengacu pada norma perilaku, asumsi, dan keyakinan (belief) dari suatu organisasi (Owens,1995). Sonhaji (1991) menyatakan bahwa budaya organisasi adalah proses sosialisasi anggota organisasi untuk mengembangkan persepsi, nilai, dan keyakinan terhadap organisasi. Berdasarkan paparan tersebut diatas dapat disimpulkan bahwa budaya organisasi berkenaan dengan keyakinan, asumsi, nilai, norma-norma perilaku, idelogi, sikap, kebiasaan, dan harapan-harapan yang dimiliki oleh organisasi ( dalam hal ini termasuk organisasi universitas swasta).

Menurut Porter (1980) terdapat beberapa faktor penentu komitmen seseorang terhadap organisasi, yaitu; 1). Komitmen dipengaruhi oleh beberapa aspek dalam lingkup pekerjaan itu sendiri yang disebut faktor organisasi. Faktor ini akan membentuk sikap bertanggung jawab terhadap keberhasilan tugas yang diemban. 2). Komitmen organisasi dipengaruhi oleh alternatif kesempatan kerja yang dimiliki pekerja yang disebut factor non-organisasi. Semakin besar peluang untuk berpindah kerja dan semakin besar hasratnya terhadap alternatif pekerjaan di tempat lain, komitmen pekerja pada organisasinya cenderung semakin rendah. 3). Komitmen pekerja pada organisasinya dipengaruhi oleh faktor karakteristik diri pekerja. Faktor ini membentuk komitmen inisial, yaitu komitmen awal yang timbul pada saat pekerja baru saja mulai masuk sebagai anggota organisasi

Dalam konteks qulity assurance, komitmen adalah suatu keyakinan dan penerimaan seseorang akan standar mutu pendidikan dan keinginannya untuk tetap melakukan peningkatan mutu pendidikan yang diselenggarakannya. Orang yang memiliki komitmen mutu yang tinggi akan cenderung menunjukkan keterlibatannya yang tinggi terhadap terjaminnya standar mutu pendidikan di lembaganya bekerja, yang itu diwujudkan bukan hanya dalam bentuk wacana dukungan tapi juga dalam bentuk sikap dan perilaku bermutu. Dan wujud sikap komitmennya akan tampak dari rasa senangnya dengan aktifitas-aktifitas yang berorientasi pada peningkatan mutu, ia tidak akan suka membuang-buang waktu dalam bekerja dan kemungkinan untuk lari dari tanggung jawab menjadi sangat kecil.

Komitmen terhadap mutu artinya lebih dari sekedar mewacanakan tentang mutu secara formalistik, tapi juga terlibat 
aktif menyenangi kegiatan-kegitan yang berorientasi pada peningkatan mutu dan bersedia untuk terus menerus mengusahakan dengan tingkat daya upaya yang tinggi bagi tersosialiasinya penjaminan mutu di perguruan tinggi, sehingga pada gilirannya dapat tercipta kultur mutu yang kondusif bagi seluruh civitas akademika.

Komitmen di sini meliputi komitmen semua pihak, baik pimpinan, tenaga edukatif, tenaga non edukatif, ataupun tenaga penunjang, dengan kata lain seluruh civitas academica.(Junaidah, n.d.)

Secara elaboratif dapat dikatakan, bahwa peningkatan mutu hanya mungkin terjadi jika diiringi dengan kegiatan penjaminan mutu yang intensif. Pelaksanaan penjaminan mutu tidak akan tercapai tanpa adanya dukungan riil dan peran sentral dari pucuk pimpinan lembaga perguruan tinggi. Karena ialah yang mampu memfasilitasi serta mengawal agar penyelenggaraan pendidikan dan pembelajaran berlangsung sesuai dengan standar yang telah ditetapkan melalui rumusan kebijakan mutu yang spesifik, jelas dan terukur. Ia memiliki 'pisau kekuasaan' untuk menjaring seluruh civitas akademika untuk sadar mutu. Melalui kebijakan pimpinan, seluruh warga kampus diajak untuk menetapkan standar mutu pendidikan dan melaksanakan penjaminan mutu secara konsisten dan serius.

Pimpinan perguruan tinggi menjadi salah satu faktor penentu keberhasilan dan berjalannya mutu pendidikan. Dalam teori Total Quality Management (TQM), ada beberapa bentuk komitmen. Bentuk komitmen diklasifikasikan ke dalam tiga dimensi, yaitu:

1) Komitmen afektif (affective commitment) yaitu adanya keterlibatan emosi pekerja terhadap organisasi. Komitmen ini dipengaruhi dan atau dikembangkan oleh adanya keinginan untuk terikat pada organisasi. Bentuk komitmen ini terjadi apabila karyawan ingin menjadi bagian dari organisasi karena adanya ikatan emosional Kunci darikomitmen ini adalah want to
2) Komitmen berkesinambungan (continuance commitment) yaitu suatu komitmen yang didasarkan akan kebutuhan rasional. Dengan kata lain, komitmen ini terbentuk atasdasar untung rugi, dipertimbangkan atas apa yang harus dikorbankan bila akan menetap pada suatu organisasi. Seseorang akan tetap bertahan pada suatu organisasi karena membutuhkan gaji dan keuntungan lain, atau karena tidak menemukan pekerjaan lain; Kunci dari komitmen ini adalah kebutuhan untuk bertahan (need to)

3) Komitmen normatif (normative commitment) yaitu komitmenyang didasarkan pada norma yang ada dalam diri karyawan, berisi keyakinan individu akan tanggung jawab terhadap organisasi. Ia merasa harus bertahan karena loyalitas. Kunci dari komitmen ini adalah kewajiban untukbertahan dalam organisasi (ought to).

Perbedaan dari ketiga bentuk komitmen ini berangkat dari ilustrasi yang dikemukakan (J.Allen \& P.Meyer, 1990): "Employees with strong affective commitment remain because they wantto, those with strong continuance commitment remain because theyneed to, and those with strong normative commitment because they feelthey thought to do so".

Pemahaman konsep kepemimpinan merupakan kombinasi tiga pandangan, yaitu: Pertama, "kepemimpinan adalah proses pengarahan dan mempengaruhi aktivitas yang berhubungan dengan tugas anggota kelompok". (Stoner dan Wankel,1986). Kedua, "kepemimpinan adalah terkait dengan pemanfaatan kekuatan orang untuk mencapai tujuan organisasi" (Wagen dan Davies, 1998). Ketiga, kepemimpinan adalah kemampuan untuk membangkitkan rasa percaya diri bawahan dan memberi dukungan kepada orang-orang untuk mencapai tujuan organisasi. (Dubrin,2010:2). Dari kombinasi ketiga pandangan ini, dapat disimpulkan bahwa hakikat kepemimpinan apapun itu termasuk kepemimpinan manajerial adalah: kemampuan untuk meyakinkan, mengarahkan, memberdayakan 
membangkitkan rasa percaya diri, dan memberikan dukungan kepada anggota kelompok/bawahan agar dapat melaksanakan aktivitas sesuai tugas pokoknya untuk mencapai tujuan organisasi. Pola Kepemimpinan ini, bila dijalankan secara maksimal oleh pimpinan perguruan tinggi/Institusi (lapisan kedua dalam model sistem penyelenggaraan pendidikan tinggi), Ketua Program Studi (ujung tombak dari lapisan ketiga dalam model sistem penyelenggaraan pendidikan tinggi), dan Dosen (salah satu unsur dari lapisan keempat dalam model sistem penyelenggaraan pendidikan tinggi), maka sistem penjaminan mutu pendidikan tinggi tidak hanya bekerja pada tataran administrasi tetapi secara maksimal juga bekerja pada tataran substansi.

Konsep tentang penjaminan mutu merupakan kombinasi dari tiga pandangan, yaitu: pertama, "pada dasarnya penjaminan mutu adalah bentuk pelepasan (devolving) tanggung jawab, desentralisasi tanggung jawab atas pengambilan keputusan di tingkat institusi pendidikan" (Kis, 2005) Kedua, "penjaminan mutu satuan pendidikan tinggi merupakan proses mendefinisikan dan pemenuhan standar manajemen mutu pendidikan tinggi secara konsisten dan berkesinambungan demi memenuhi kebutuhan seluruh pihak yang berkepentingan seperti peserta didik, orang tua, industri, pemerintah, dosen, staf pendukung, dan pihak-pihak terkait lainnya" (Amaripuja,2007). Ketiga, "Merencanakan, mencapai, memelihara, dan meningkatkan mutu pendidikan secara berkelanjutan pada satuan pendidikan tertentu merupakan tujuan penjaminan mutu secara umum" (Rusman,2009). Dari kombinasi pandanganpandangan tersebut, maka terungkap beberapa makna sebagai berikut: (1) tanggung jawab tentang mutu pendidikan tinggi sepenuhnya diserahkan kepada dan menjadi tanggung jawab perguruan tinggi yang bersangkutan. Dari hakikat penjaminan mutu inilah, maka direktorat Jenderal Pendidikan Tinggi sebagai Otoritas Pusat mereduksi fungsinya menjadi facilitating, empowering, dan enabling berdasarkan HELTS 2003-2010, (2) terdapat dua kegiatan kunci penjaminan mutu pendidikan tinggi yaitu penetapan dan pemenuhan standar managemen mutu pendidikan tinggi pada perguruan tinggi yang bersangkutan, (3) mutu pendidikan tinggi harus direncanakan, dicapai, dipelihara, dan ditingkatkan secara konsisten dan berkelanjutan, (4) mutu lulusan perguruan tinggi harus memenuhi harapan seluruh stakeholders.

Standar mutu adalah kriteria yang menunjukkan tingkat capaian kinerja yang diharapkan, yang digunakan untuk mengukur dan menjabarkan persyaratan mutu serta prestasi kerja dari individu ataupun unit kerja. Standar Mutu Akademik adalah tingkat capaian kinerja akademik dosen dan mahasiswa dalam pendidikan/pengajaran, penelitian, dan pengabdian kepada masyarakat. Pencapaian standar mutu akademik setiap individu akan mencerminkan pencapaian standar mutu akademik unit kerjanya. Standar mutu berbentuk pernyataan yang dapat berbentuk penjabaran/rincian karakteristik, perintah untuk melakukan sesuatu, atau pernyataan tentang sesuatu yang harus terjadi/dicapai.

Penjaminan mutu dasarnya adalah "trust" kepercayaan dan disitulah peran Undang-Undang No. 20 Tahun 2003 pasal 60 tentang akreditasi dan pasal 61 tentang sertifikasi yang secara laungsung berkaitan dengan penjaminan mutu, akreditasi dan sertifikasi sebagai bagian penting dari akuntabilitas publik di bidang pendidikan.

Dalam hubungan itu para stakeholders telah menuntut lembaga - lembaga penyelenggara dan penanggung jawab pendidikan untuk lebih profesional dan untuk itu Badan Standar Nasional Pendidikan (BSNP) amat menekankan persoalan mutu tersebut dengan menghadirkan sejumlah standar nasional pendidikan baik secara terukur (kuantitatif) dan dengan juga tetap memperhatikan dimensi soft skills lainnya. Supaya hal itu terjadi maka manajemen mutu perguruan tinggi (Quality Management) harus dikelola dengan baik. 


\section{PEMBAHASAN}

\section{Potret Pelaksanaan Penjaminan Mutu Di STKIP PGRI Tulungagung}

Tidak dipungkiri, bahwa salah satu hal penting di sebuah lembaga pendidikan ialah dikelolanya penjaminan mutu dengan baik, serta adanya kepedulian semua pihak untuk terus meningkatkan dan memperbaiki mutu pendidikan. Kebijakan pimpinan lembaga pendidikan untuk melaksanakan penjaminan mutu secara konsisten dan serius, menjadi salah satu faktor penentu keberhasilan mutu pendidikan. Untuk itulah semua pimpinan lembaga pendidikan harus terus mengupayakan berbagai hal agar mutu pendidikan yang dikelolanya terjamin dan bisa bersaing dengan pendidikan lainnya yang sudah terlebih dahulu berkualitas.

Demikian pula halnya dengan STKIP PGRI Tulungagung yang saat ini telah dan akan terus mengupayakan terlaksananya Sistem penjaminan mutu di lembaga tersebut. Dalam kerangka itulah, Badan Penjaminan Mutu (BPM) STKIP PGRI Tulungagung pada awalnya dibentuk di bawah kepemimpinan Drs. Aries Yuwono, M.Pd. Namun oleh karena pembentukannya hadir sekedar pemenuhan kebutuhan formal kelembagaan dan tampak terkesan politis, maka lembaga tersebut pun belum banyak melakukan kegiatan berarti. Peralihan kepemimpinan di Badan Penjaminan Mutu sudah dilakukan hingga empat kepemimpinan, namun belum juga mampu menunjukan kinerja kelembagaan yang idealnya melakukan pengendalian dan pengembangan mutu kelembagaan sehingga pelaksanaan tiap program sesuai dengan perencanaan dengan indikator kinerja yang terukur serta dapat memberikan saran dan masukan terhadap pelaksanaan program setiap unit kerja di lingkungan STKIP PGRI Tulungagung.

Oleh karena secara struktural kelembagaan BPM di lingkup institut belum berjalan dengan baik, maka pada lingkup internal Prodi pun, jaminan mutu cenderung tidak berjalan dengan baik. Beberapa aktivitas mutu yang idealnya sudah dilakukan oleh tim kendali mutu di tingkat
Prodi seperti melakukan pemantauan dan evaluasi terhadap pelaksanaan semua program/kegiatan manajemen akademik serta program pengembangan pendidikan di Prodi, diantaranya kinerja Dosen, tingkat kepuasan mahasiswa, efisiensi dan efektivitas kurikulum belum tampak memuaskan. Sehingga ketika ada dorongan secara nasional untuk mengikuti akreditasi jurusan/prodi, para pemangku kebijakan tampak kelihatan 'tergopoh-gopoh' mengumpulkan data dan dokumen, bahkan beberapa dilakukan dengan manipulatif demi memenuhi akreditasi standar yang diharapkan oleh lembaga.

Badan Penjaminan Mutu hanya terdiri dari dua orang tenaga fungsional yang menjabat sebagai kepala BPM dan sekretaris. Realitas ini begitu miris bila dibandingkan dengan struktur lembaga penjaminan mutu diberbagai perguruan tinggi lainnya. Karena bagaimana mungkin kerja-kerja monitoring dan evaluasi (monev) beserta pengembangan mutu akademik dapat dipikul oleh hanya dua orang tersebut. Kenyataan ini menjadi 'batu sandungan' yang sangat berarti bagi obsesi implementasi penjaminan mutu yang diharapkan.

Belum lagi, keberadaan dokumendokumen mutu yang ada di lembaga STKIP PGRI Tulungagung. Bila dikatakan bahwa STKIP belum memiliki dokumen dan SPMI (Sistem Penjaminan Mutu Internal), realitasnya STKIP telah memiliki dokumen tersebut. Namun sayangnya, dokumen tersebut ada namun tampak tiada. Bagaimana tidak. Dokumen itu bukan berangkat dari hasil kebutuhan lapangan dan tidak ada proses kontekstualisasi dengan realitas akademik yang ada di lembaga, Ia hadir hanya sebagai formalitas memenuhi administrasi kelembagaan, alih-alih untuk kepentingan akreditas semata. Sehingga pembuatannya pun sering terdapat copy paste dari dokumen yang dibuat oleh perguruan tinggi lainnya, sehingga tidak realistis, membumi dan pada gilirannya tidak dapat tersosialisasi apalagi menjadi standar bagi terlaksananya penjaminan mutu akademik di tingkat praksis kelembagaan. 
Kondisi ini semakin diperkeruh pula oleh minimnya kebijakan anggaran yang pro mutu. Kebijakan anggaran masih terorientasi pada pembangunan fisik bangunan ketimbang non- fisik, termasuk pembangunan kultur mutu di STKIP PGRI Tulungagung, sehingga implikasinya dapat terlihat rapat-rapat monitoring evaluasi jarang dilakukan dan berbagai kegiatan pengembangan mutu, pembahasan dokumen mutu hampir sulit difasilitasi oleh lembaga. Disamping tentu aja, sarana prasarana bagi terlaksanakan penjaminan mutu yang kurang direspon oleh lembaga.

Realitas faktual tersebut tentu saja membuat langkah perbaikan mutu menjadi berjalan tersendat-sendat. Beberapa pimpinan yang pernah menjabat di BPM (Badan Penjaminan Mutu) banyak yang mengeluh, tidak bisa berbuat banyak, bahkan ada yang frutasi atas realitas yang ada sehingga mengundurkan diri dari struktur kelembagaan BPM. (wawancara dengan Ketua STKIP PGRI Tulungagung, tanggal 18 September 2018)

Terlepas dari berbagai kendala yang ada, dan seiring dengan kebijakan nasional tentang struktur kelembagaan penjaminan mutu, maka 'greget' mutu di lingkungan STKIP PGRI Tulungagung pun mulai tahun 2013 ini mulai menampakan hasilnya dengan perbaikan sistem pengajaran, berjalannya monitoring Evaluasi dosen yang secara reguler diekpos melalui rapat dosen, peninjauan kembali silabus dan SAP Dosen, perbaikan fasilitas belajar mahasiswa dan terfokusnya penjaminan mutu dan beban kerja dosen di lingkungan STKIP PGRI Tulungagung. (wawancara dengan Ketua Penjaminan Mutu, tanggal 20 September 2018)

Memang aspek aspek mutu itu cukup banyak dan belum sepenuhnya bisa dilaksanakan oleh Badan Penjaminan Mutu (BPM) yang ada, tetapi dengan usaha yang terus menerus dilakukan, tim pengelola BPM yakin bahwa pada saatnya nanti keseluruhan aspek akan bisa dilaksanakan dengan baik. Proses yang dilakukan menuju budaya mutu memang tidak dapat instan alias harus bertahap, karena kalau harus lengkap meliputi keseluruhan aspek terseburt, barangkali tidak akan pernah terlaksana. Namun bila dipetakan faktor penghambat terbesar dari terlaksanakan sistem penjaminan mutu di STKIP PGRI Tulungagung adalah berangkat dari kebijakan mutu dan komtmen pimpinan dalam rangka menciptakan kultur mutu di lingkungan kampus.

\section{Peran dan Gaya Kepemimpinan dalam Pelaksanaan Penjaminan Mutu}

Peningkatan kualitas pendidikan tinggi dapat dilihat dari dua dimensi, yaitu kualitas proses dan produk atau hasil. Suatu pendidikan dikatakan berkualitas dari segi proses bila proses pembelajaran berlangsung efektif dan bermakna serta ditunjang dengan sumber daya yang memadai. Proses pendidikan yang berkualitas memberikan jaminan mengenai kualitas produk yang dihasilkan. Agar proses pendidikan berkualitas, diperlukan pemimpin yang pasti mempunyai sejumlah harapan-harapan dan untuk merealisasikannya dibuat suatu struktur kewenangan supaya dapat dijadikan sebagai suatu acuan para pelaku didalamnya dalam berperilaku.

Sejumlah harapan itu biasanya berorientasi ke arah masa depan dan dikenal dengan sebutan visi. Sejalan dengan pernyataan sallis (1993:96), yang menjelaskan bahwa "Pernyataan visi mengkomunikasikan pokok-pokok tujuan lembaga dan untuk apa lembaga tersebut berdiri." lebih lanjut Salis (1993:97) mengungkapkan, bahwa "Dan Pemimpin lah aktor yang harus memiliki visi dan mampu menerjemahkan visi tersebut ke dalam kebijakan yang jelas dan tujuan yang spesifik."

Dari pernyataan di atas tampak bahwa pimpinan dalam sebuah institusi (baca: perguruan tinggi) mempunyai peran yang sangat penting dalam pelaksanaan penjaminan mutu. Ia memiliki potensi menciptakan visi dan menterjemahkannya ke dalam kenyataan serta berperan sebagai kekuatan sentral dalam menggerakkan 
kehidupan kampus, juga memahami tugas dan fungsinya dalam mengembangkan mutu pendidikan.

Dalam pelaksanaan manajemen peningkatan mutu, pimpinan harus senantiasa memahami bahwa perguruan tinggi adalah suatu lembaga yang memiliki sistem organik. Untuk itu, ia harus lebih berperan sebagai pemimpin dibandingkan sebagai manager. Seorang manajer dalam institusi perguruan tinggi harus memiliki kompetensi untuk memberi arahan, visi dan inspirasi. Seluruh manajer harus menjadi pemimpin dan pejuang proses mutu. Mereka harus mengkomunikasikan visi ke seluruh orang dalam institusi, termasuk di dalamnya perubahan dalam pola pikir manajemen serta perubahan peran. Peran tersebut berubah dari mentalis 'saya adalah bos' menuju mental bahwa manajer adalah pendukung dan pemimpin para staf.

Namun dalam realitasnya, peran pimpinan STKIP PGRI Tulungagung dalam mengimplementasikan penjaminan mutu melalui kebijakan mutu sehingga terciptanya budaya mutu yang diharapkan, belum dapat berlangsung secara optimal. Permasalahan ini terjadi karena disamping belum terinternalisasi dan terimplementasinya konsep TQM (Total Quality Management) dan prinsip leadership di atas dalam pelaksanaan kepemimpinan di STKIP PGRI Tulungagung, juga dikarenakan gaya kepemimpinan (leadership styles) sebagai refleksi dari pelaksanaan fungsi-fungsi kepemimpinannya dan kepribadian masingmasing pemimpin yang berbeda-beda.

Terkait dengan gaya kepemimpinan (leadership styles) ini, ada preposisi yang menarik yang diungkapkan oleh Peters dan Austin dalam penelitiannya, yang kemudian dibukukan dalam judul buku: A Passion for Excellence. Penelitian tersebut meyakinkan masyarakat umum bahwa diantara indikatorindikator penentu kepuasan dan prestasi kerja serta terciptanya budaya mutu di perguruan tinggi adalah melalui gaya kepemimpinan seorang leader. Gaya kepemimpinan dipandang sebagai salah satu prediktor penting yang menentukan mutu dalam sebuah institusi. Mereka berpendapat bahwa gaya kepemimpinan tertentu dapat mengantarkan institusi pada revolusi mutu. Kesuksesan organisasi dalam mencapai tujuan dan sasaran mutu tergantung pada manajer dan gaya kepemimpinannya.

Studi kepemimpinan Universitas Michigan yang dipelopori oleh Gibson dan Ivancevich (2004:413) mengidentifikasikan dua bentuk gaya kepemimpinan yaitu:

1. Gaya kepemimpinan yang berorientasi pada tugas (The Job Centered). Dalam gaya kepemimpinan ini, seorang manajer akan mengarahkan dan mengawasi bawahannya agar sesuai dengan yang diharapkan manajer. Manajer yang mempunyai gaya kepemimpinan ini lebih mengutamakan keberhasilan dari pekerjaan yang hendak dicapai daripada perkembangan kemampuan bawahannya.

2. Gaya kepemimpinan yang berorientasi pada bawahan (The Employee Centered). Manajer yang mempunyai gaya kepemimpinan ini berusaha mendorong dan memotivasi pekerjanya untuk bekerja dengan baik. Mereka mengikutsertakan pekerjanya dalam mengambil suatu keputusan.

Perkembangan modern memunculkan konsep baru tentang gaya kepemimpinan yang ditawarkan oleh Peters dan Austin dalam penelitiannya, yakni dengan nama MBWA (Management by Walking About atau manajemen dengan melaksanakan). Menurut keduanya, keinginan untuk unggul tidak bisa dikomunikasikan dari balik meja. Ia membutuhkan keterlibatan langsung pimpinan yang secara praksis dan partisipatif terjun langsung membantu tim penjaminan mutu dalam melaksanakan tugasnya. Karena konsep MBWA ini menekankan komunikasi visi dan nilai-nilai institusi kepada pihakpihak lain, serta berbaur dengan para staf dan pelanggan.

Bila Konsep ide MBWA di atas realiable dan mampu diimplementasikan oleh seorang pemimpin perguruan tinggi, tentu saja, hal itu akan membawa dampak perubahan yang kondusif bagi munculnya budaya mutu sehingga tercapai keberhasilan mutu 
pendidikan di lembaga tersebut. Namun demikian, dari hasil survey peneliti tentang gaya kepemimpinan pada lingkungan STKIP PGRI Tulungagung menunjukan banyak temuan yang berbeda secara diametral dengan idealitas konsep di atas. Beberapa responden menyebutkan, bahwa mayoritas pimpinan di STKIP PGRI Tulungagung sebagaimana berikut:

1. Pemimpin lebih menekankan kepada pelaksanaan tugas daripada pembinaan dan pengembangan bawahan.

2. Pemimpinan kurang mengapresiasi kinerja bawahan dan tidak pula memberlakukan reward terhadap bawahan yang memiliki prestasi dalam melaksanakan tugas.

3. Pemimpin juga tidak memberlakukan punishment secara tegas dan efektif terhadap bawahan yang melakukan kesalahan dalam melaksanakan tugas, sehingga melahirkan kesalahan-kesalahan baru yang diikuti oleh pelaku yang lain.

4. Pengarahan dari pimpinan mengenai mekanisme kerja masih kurang efektif sehingga pegawai cenderung melaksanakan pekerjaan sesuai dengan persepsinya sendiri.

5. Pemimpin kurang memberikan kepercayaan kepada bawahan dalam menyelesaikan tugas.

6. Pembagian tugas dan pelimpahan wewenang masih belum dapat dikomunikasikan dengan baik oleh pimpinan kepada bawahan.

7. Pemimpin tidak responsif, artinya pemimpin tersebut kurang tanggap terhadap setiap persoalan, kebutuhan, maupun harapan dari bawahannya.

8. Pemimpin kurang aktif dan proaktif dalam mencari solusi dari setiap permasalahan ataupun tantangan yang dihadapi.

Meskipun karena itu pulalah, pembahasan selamjutnya akan lebih banyak menyupas tentang komitmen mutu pimpinan STKIP PGRI Tulungagung.

\section{Komitmen Mutu Pimpinan dalam Meningkatkan Mutu Pendidikan di STKIP PGRI Tulungagung}

Dalam konteks qulity assurance, komitmen adalah suatu keyakinan dan penerimaan seseorang akan standar mutu pendidikan dan keinginannya untuk tetap melakukan peningkatan mutu pendidikan yang diselenggarakannya. Orang yang memiliki komitmen mutu yang tinggi akan cenderung menunjukkan keterlibatannya yang tinggi terhadap terjaminnya standar mutu pendidikan di lembaganya bekerja, yang itu diwujudkan bukan hanya dalam bentuk wacana dukungan tapi juga dalam bentuk sikap dan perilaku bermutu. Dan wujud sikap komitmennya akan tampak dari rasa senangnya dengan aktifitas-aktifitas yang berorientasi pada peningkatan mutu, ia tidak akan suka membuang-buang waktu dalam bekerja dan kemungkinan untuk lari dari tanggung jawab menjadi sangat kecil.

Hal ini sejalan dengan pandangan Richard M. Steers (1979) yang berpendapat bahwa komitmen terhadap mutu artinya lebih dari sekedar mewacanakan tentang mutu secara formalistik, tapi juga terlibat aktif menyenangi kegiatan- kegitan yang berorientasi pada peningkatan mutu dan bersedia untuk terus menerus mengusahakan dengan tingkat daya upaya yang tinggi bagi tersosialiasinya penjaminan mutu di perguruan tinggi, sehingga pada gilirannya dapat tercipta kultur mutu yang kondusif bagi seluruh civitas akademika.

Pendapat ini diperkuat oleh Pradiansyah (1999:31) yang menguraikan bahwa komitmen mutu merupakan konsep manajemen yang menempatkan sumber daya manusia sebagaifigur sentral dalam organisasi mutu.Tanpa komitmen, sukar mengharapkan partisipasi aktif dan mendalam dari sumber daya manusia.Tapi komitmen bukanlah sesuatu yang dapat hadir begitu saja.Komitmen harus dilahirkan.Oleh sebab itu, komitmen harus dipelihara agar tetap tumbuh dan eksis di sanubari sumber daya manusia.Dan komitmen yang terbaik dalam dunia perguruan tinggi adalah komitmen yang dimulai dari pimpinan. Dari 
unsur pimpinan inilah kemudian virus komitmen itu ditularkan kepada bawahanbawahannya, dan melalui cara dan teknik yang tepat sasaran, pimpinan yang baik akan dapat menciptakan dan menumbuhkan komitmen itu pada semua staf di bawahnya.

\section{KESIMPULAN}

Sistem penjaminan mutu di STKIP PGRI Tulungagung belum dilaksanakan sesuai dengan aturan perundang-undangan yang berlaku yang terencana, sistematis dan berkelanjutan secara konsiten, hal ini ditunjukkan bahwa STKIP PGRI Tulungagung belum memiliki dokumen sistem penjaminan mutu yang komprehensip berdasarkan Standar Pendidikan Tinggi.

Hambatan pelaksanaan penjaminan mutu di STKIP PGRI Tulungagung adalah (a) belum tersedianya panduan sistem penjaminan mutu k; (b) komitmen pimpinan; (c) Anggaran Infrastruktur akademik; (d) dukungan SDM; dan (e) sistem informasi teknologi.

Strategi Peningkatan Sistem Penjaminan Mutu di STKIP PGRI Tulungagung melalui peningkatan komitmen dan kesadaran mutu, serta implementasi budaya mutu bagi pimpinan dan civitas akademika STKIP PGRI Tulungagung

\section{DAFTAR PUSTAKA}

Aranya. (n.d.). Are-examination of Accountan Organizational Profesional Conflict.

J.Allen, N., \& P.Meyer, J. (1990). The Measurement and antecedents of affective, continuance and normative commitment to the organization.

Junaidah. (n.d.). KONTRIBUSI PEMIMPIN PENDIDIKAN

DALAM

MENINGKATKAN

MUTU

PENDIDIKAN DI PERGURUAN

TINGGI, 75-99.

Kis, V. (2005). Quality Assurance in Tertiary Education: Current Practices in OECD Countries and a Literature Review on Potential Effects. Organisation for Economic Co-operation and Development. Directorate for
Education. Education and Training Policy Division, (August), 47. Diambil dari

http://www.oecd.org/education/skillsbeyond-school/38006910.pdf

Luthans, F. (2012). Organizational behavior an evidence-based approach 12th edition. Organizational behavior: an edivence-based approach.

Pandey, B. (2011). Pengaruh Kualitas Sumber Daya Manusia, Sarana Pendudkung dan Komitmen Pimpinan Terhadap Kinerja Satuan Kerja Perangkat Daerah (SKPD) Dalam Menyusun Laporan Keuangan SKPD di Lingkungan Pemerintah Provinsi Sulawesi Utara, (2), 60-73.

Pendidikan, D. (2003). Pedoman penjaminan mutu.

Porter, M. E. (1980). Competitive strategy: Techniques for analyzing industries and companies. New York. Diambil dari http://www.vnseameo.org/ndbmai/CS.p df

Robbins, S. (2013). Organizational Behavior. Zhurnal Eksperimental'noi $i$ Teoreticheskoi Fiziki. https://doi.org/10.12737/4477 